Gut, 1988, 29, 603-607

\title{
DNA aneuploidy and cell proliferation in familial adenomatous polyposis
}

\author{
P QUIRKE, M F DIXON, D W DAY, J B J FOZARD, I C TALBOT, \\ AND C C BIRD \\ From the Departments of Pathology, the Universities of Leeds, Liverpool, Leicester, and Edinburgh and the \\ University Department of Surgery, St James's Hospital, Leeds
}

SUMmaRy Two hundred and thirteen samples from 20 patients with familial adenomatous polyposis (FAP) were investigated by flow cytometry and the results compared with 100 sporadic adenomas. Eleven of the $20(55 \%)$ yielded one or more DNA aneuploid samples with an overall incidence within FAP adenomas of $12 \%$. Despite a similar level of DNA aneuploidy in sporadic adenomas, it was commonly detected at a smaller polyp size. The degree of cell proliferation was found to be similar in the two groups (median $\% S+G_{2} 15.8 \% v 16.4 \%$ ) but larger FAP adenomas demonstrated a higher level of cell proliferation than smaller adenomas. DNA aneuploidy had no value as a predictor of a synchronous carcinoma and appeared to be an early change in the development of carcinoma in these patients.

DNA aneuploidy has been described in $6-13 \%$ of unselected sporadic colorectal adenomas ${ }^{1-3}$ and appears related to the size and type of adenoma, though there is disagreement about its relationship to dysplasia $^{23}$ the grading of which is known to be highly subjective. ${ }^{4}$ In the dominantly inherited condition of familial adenomatous polyposis (FAP) large numbers of adenomas develop synchronously throughout the colorectum and are associated with the almost inevitable development of carcinoma after a variable period of time if the large bowel is not removed. ${ }^{5}$ We have investigated the presence of DNA aneuploidy and the degree of cell proliferation in a group of patients with FAP and compared these findings with those in the sporadic type of adenoma ${ }^{2}$ in an attempt to identify biological differences between the two entities.

\section{Methods}

\section{PATIENTS}

Cases of FAP were identified from the General Infirmary and St James's Hospital, Leeds, Leicester

Address for correspondence: Dr P Quirke, Department of Pathology, University of Leeds, Leeds.

Received for publication 16 November 1987
Royal Infirmary, and the Royal Liverpool Hospital. Age, sex, and family relationships between patients were noted for comparison with flow cytometric data. Two hundred and thirteen samples were selected from $20 \mathrm{FAP}$ cases, the number of adenomas per case ranging from $2-48$ (mean number $=10 \cdot 53$ ). Eight adenocarcinomas from these cases were also analysed. All specimens were total or subtotal colectomy specimens except for a single rectal stump resection.

\section{HISTOPATHOLOGY}

Paraffin sections were cut at $5 \mu \mathrm{m}$ and stained by haematoxylin and eosin. The adenomas were coded, measured from the slide and classified as to type and grade of dysplasia by a single pathologist using previously described criteria.$^{6-8}$ Adenomas ranging in size from $1-5 \mathrm{~mm}$ in diameter were classified as early adenomas and those $<1 \mathrm{~mm}$ - that is, evident only on microscopy, microadenomas. Mucosae bearing no lesions were classified as normal. Early adenomas and microadenomas were not further characterised on the basis of grades of dysplasia or histological growth pattern because of the frequent presence of more than one adenoma within any section.

In one case the formalin fixed colon and a prior 
abdominoperineal excision of rectum from a patient with familial polyposis coli were available for study. Fifty adenomas were removed from this colon, half of each adenoma was embedded for histopathological examination and the other half processed for flow cytometry. Three synchronous carcinomas were examined from the abdominoperineal exicision specimen.

\section{FLOW CYTOMETRY}

Thick $50 \mu \mathrm{m}$ sections were cut and prepared as previously described ${ }^{2}$ for flow cytometry using the method of Hedley et al. ${ }^{9}$ In the case of formalin fixed material the tissue was minced with a scalpel blade and prepared by an identical procedure except for the omission of the rehydration steps. DNA histograms of 10000 nuclei were collected and the diploid cases analysed by a cell cycle program. The percentage of proliferating cells was derived from analysis of the DNA distribution using the computer software PARA 1 (Coulter Electronics, Hialeh, Florida). The percentage of cells in the $S, G_{2}$ and early stages of mitosis were quantified and called the $\% \mathrm{~S}+\mathrm{G}_{2}$. Cells in middle and late phases of mitosis lack a nuclear membrane and are destroyed by the nuclear isolation technique. The total proliferative fraction $\left(\% S+G_{2}\right)$ was utilised instead of the $\% \mathrm{~S}$ phase as the former is more accurate and reproducible when performing measurements using PARA $1 .^{10}$ DNA aneuploidy was defined by the presence of two $G_{0} / G_{1}$ peaks ${ }^{11}$ and the DNA index as the ratio of the abnormal $G_{0} / G_{1}$ peak modal channel number to the diploid $G_{0} / G_{1}$ peak modal channel number. For example a DNA aneuploid tumour DNA histogram might give rise to a diploid $G_{0} / G_{1}$ peak at channel 50 and a DNA aneuploid $G_{0} / G_{1}$ peak at channel 75 . The ratio of 50:75 yields a DNA index of 1.5 - that is, the abnormal cells have one and a half times the DNA content of the diploid cells. DNA stemlines (tumour cell $G_{0} / G_{1}$ peaks), were considered to be related if the DNA indices fell within $\pm 0 \cdot 2$ - that is, tumours showing DNA indices of 1.5 and 1.7 would be considered related. One hundred diploid sporadic adenomas were also randomly selected from a previous series ${ }^{2}$ and cell cycle analysis performed to assess the level of cell proliferation in this group. The median coefficient of variation was $7 \%$.

\section{Results}

CLINICAL AND HISTOPATHOLOGICAL FEATURES Of the 20 FAP patients, nine were blood relatives; four were sibling pairs, and one an uncle of a sibling pair. Ages ranged from 12-58 years, 11 were male and nine female. Four patients had a total of eight adenocarcinomas in their specimens; the median age

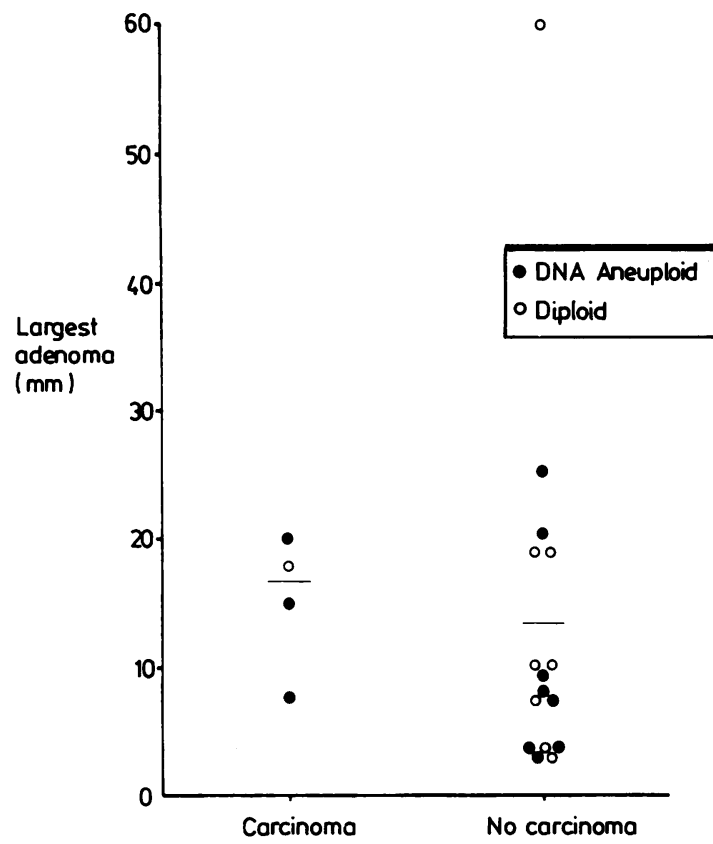

Fig. 1 Size of largest adenoma versus the presence of a carcinoma and the DNA content in FAP patients. The bar represents the median value.

of patients with carcinomas was 34 years compared with 26 years for those without ( $p=$ NS MannWhitney U Test). Information about the size of the largest adenoma found in each colectomy specimen was retrieved from the original histopathology report and compared with the presence of carcinoma. The largest size of adenoma in carcinoma bearing patients had a median value of $16.5 \mathrm{~mm}$ and in non-carcinoma bearing patients $8.5 \mathrm{~mm}$ (Fig. 1: $\mathrm{p}=\mathrm{NS}$ MannWhitney U test).

\section{DNA CONTENT}

Nine of $20(45 \%)$ colons yielded purely diploid specimens whereas $11(55 \%)$ contained one or more DNA aneuploid samples; the overall incidence of DNA aneuploidy in the FAP samples was $11.9 \%$. There was no difference between age at time of operation and presence of a diploid (median 26 years) or DNA aneuploid (median 26 years) profile (Fig. 2). The relationship of DNA aneuploidy to histopathological features is shown in Table 1. DNA aneuploidy was not seen in four normal mucosae studied but was present in microadenomas $(<1 \mathrm{~mm})$, early adenomas $(<5 \mathrm{~mm})$, and 5-9 mm adenomas; surprisingly it was not shown in adenomas of 10-19 $\mathrm{mm}$ size though one of three very large $(>20 \mathrm{~mm})$ adenomas was DNA aneuploid. An increasing incidence of DNA aneuploidy was observed as the 


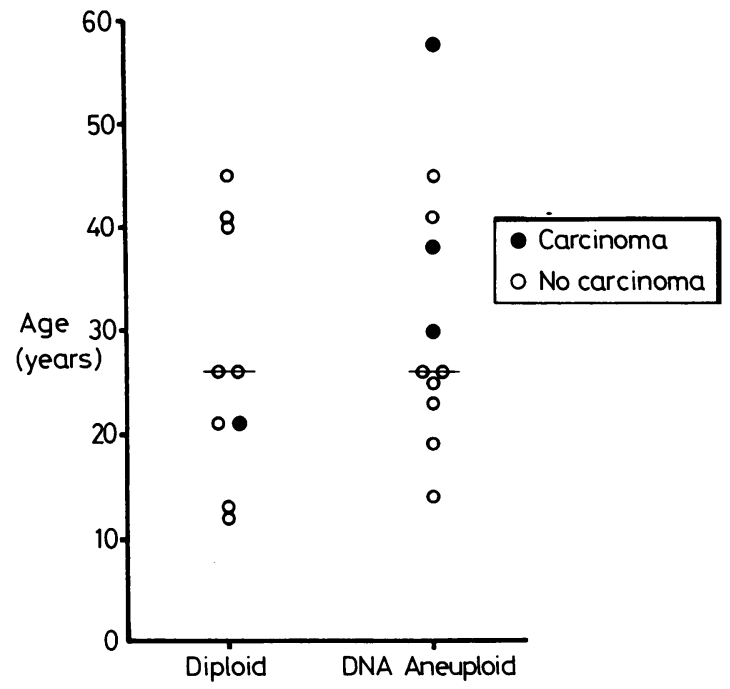

Fig. 2 Age at operation versus DNA content and the presence of carcinoma in FAP patients. The bar represents the median value.

severity of dysplasia increased and with a change from tubular to villous architecture. None of these relationships reached statistical significance.

In three of the four related pairs of patients DNA aneuploidy was found in one sibling but not the other. In the fourth pair, DNA aneuploidy was demonstrable in the left part of the colon in each member; in one brother with DNA stemlines (abnormal $G_{0} / G_{1}$ peaks) of 1.3 and 1.6 in different parts of the colon whilst in the other a single DNA stemline of 1.3 was found.

FAP CELL PROLIFERATION

Results of the cell proliferation measurements $\left(\% \mathrm{~S}+\mathrm{G}_{2}\right)$ are shown in Table 2 for size of adenomas and Table 3 for the type of adenomas and degree of dysplasia. The median $\% \mathrm{~S}+\mathrm{G}_{2}$ value was $15 \cdot 8 \%$ (range $5 \cdot 5 \%-30 \cdot 5 \%$ ). No significant differences were observed between the level of cell proliferation and type of adenoma or severity of dysplasia. Significant differences were found, however, between small and large adenomas when microadenomas and early adenomas $(<5 \mathrm{~mm})$ were compared with those of $5 \mathrm{~mm}$ or greater with median values of $15.4 \% v$ $18.6 \%$ ( $p<0.005$ Mann-Whitney U test). This was confirmed by a Kruskal Wallis test comparing five groups of differing size of adenoma $(p<0.005)$.

\section{SPORADIC ADENOMA CELL PROLIFERATION}

The distribution of $\% \mathrm{~S}+\mathrm{G}_{2}$ values in 100 randomly selected diploid adenomas when related to size, architectural type and severity of dysplasia are shown in Table 4. The median $\% S+\mathrm{G}_{2}$ value was $16.4 \%$ (range $6.98-32.9 \%$ ). No relationship was demonstrable between these measurements and the histopathological assessments apart from a lower median cell proliferation in mildly dysplastic adenomas $(12 \cdot 8 \%)$. The median $\% S+G_{2}$ values did not differ significantly from those found in FAP adenomas $(16.4 \% v 15.8 \%)$.

\section{Discussion}

The naturally occurring model of FAP is unique in allowing investigation of the development of multiple adenomas under the same environmental and genetic influences. Its rarity limited this study to 20 cases, but the clinical and histopathological findings confirm previous reports of the development of carcinoma in an older age group of patients and the tendency of patients with carcinoma to have larger synchronous adenomas. ${ }^{51213}$

DNA CONTENT

The presence of DNA aneuploidy in the adenomas of $55 \%$ of all patients with FAP and its finding in $40 \%$ of

Table 1 Relationship of DNA content of 213 samples from 20 cases of FAP to pathological features

\begin{tabular}{|c|c|c|c|c|c|c|c|c|}
\hline & \multirow{2}{*}{$\begin{array}{l}\text { Normal } \\
\text { mucosa }\end{array}$} & \multirow{2}{*}{$\begin{array}{l}\text { Micro- } \\
\text { adenomas } \\
(<1 \mathrm{~mm})\end{array}$} & \multirow{2}{*}{$\begin{array}{l}\text { Early } \\
\text { adenomas } \\
(<5 \mathrm{~mm})\end{array}$} & \multicolumn{3}{|c|}{ Size of adenoma } & \multirow[b]{2}{*}{$20+m m$} & \multirow[b]{2}{*}{ Carcinoma } \\
\hline & & & & $5-9 \mathrm{~mm}$ & $10-14 \mathrm{~mm}$ & $15-19 \mathrm{~mm}$ & & \\
\hline \multirow[t]{3}{*}{$\begin{array}{l}\text { Diploid } \\
\text { DNA aneuploid } \\
\% \text { DNA aneuploid }\end{array}$} & \multirow[t]{3}{*}{$\begin{array}{l}4 \\
0 \\
0\end{array}$} & $\begin{array}{c}28 \\
5 \\
15 \cdot 2\end{array}$ & $\begin{array}{l}52 \\
11 \\
17 \cdot 5\end{array}$ & $\begin{array}{c}59 \\
7 \\
11 \cdot 1\end{array}$ & $\begin{array}{r}27 \\
0 \\
0\end{array}$ & $\begin{array}{l}9 \\
0 \\
0\end{array}$ & $\begin{array}{c}2 \\
1 \\
33 \cdot 3\end{array}$ & $\begin{array}{l}5 \\
3 \\
37 \cdot 5\end{array}$ \\
\hline & & \multicolumn{4}{|l|}{ Dysplasia } & \multicolumn{3}{|l|}{ Type } \\
\hline & & Mild & Moderate & \multicolumn{2}{|c|}{ Severe } & Tubular & Tubulovillous & Villous \\
\hline $\begin{array}{l}\text { Diploid } \\
\text { DNA aneuploid } \\
\% \text { DNA aneuploid }\end{array}$ & & $\begin{array}{l}43 \\
1 \\
2 \cdot 3\end{array}$ & $\begin{array}{l}39 \\
4 \\
9 \cdot 3\end{array}$ & $\begin{array}{r}15 \\
3 \\
16\end{array}$ & & $\begin{array}{l}46 \\
2 \\
4 \cdot 2\end{array}$ & $\begin{array}{l}48 \\
5 \\
9 \cdot 4\end{array}$ & $\begin{array}{r}3 \\
1 \\
25\end{array}$ \\
\hline
\end{tabular}


Table 2 Relationship of median $\% S+G_{2}$ of 171 adenomas from 20 cases of FAP to size of adenoma

\begin{tabular}{|c|c|c|c|c|c|c|c|}
\hline & \multirow{2}{*}{$\begin{array}{l}\text { Normal } \\
\text { mucosa }\end{array}$} & \multirow{2}{*}{$\begin{array}{l}\text { Microadenomas } \\
(<1 \mathrm{~mm})\end{array}$} & \multirow{2}{*}{$\begin{array}{l}\text { Early adenomas } \\
(<5 \mathrm{~mm})\end{array}$} & \multicolumn{4}{|c|}{ Size of adenoma } \\
\hline & & & & $5-9 \mathrm{~mm}$ & $10-14 \mathrm{~mm}$ & $15-19 \mathrm{~mm}$ & $>20 \mathrm{~mm}$ \\
\hline Samples (n) & 4 & 38 & 42 & 62 & 23 & 10 & 2 \\
\hline Median $\% \mathrm{~S}+\mathrm{G}_{2}$ & $14 \cdot 1$ & 14.9 & $17 \cdot 7$ & $18 \cdot 5$ & $19 \cdot 5$ & $18 \cdot 0$ & $15 \cdot 8$ \\
\hline Range & $12 \cdot 4-21 \cdot 4$ & $9 \cdot 0-27.4$ & $5 \cdot 6-28 \cdot 0$ & $5 \cdot 5-33.9$ & $9 \cdot 6-31 \cdot 5$ & $11 \cdot 1-25 \cdot 6$ & $14 \cdot 3-17 \cdot 4$ \\
\hline 25 th -75 th centile & $12 \cdot 5-19 \cdot 9$ & $13 \cdot 2-19 \cdot 4$ & $13 \cdot 5-20 \cdot 2$ & $14 \cdot 2-22 \cdot 4$ & $17 \cdot 4-23 \cdot 2$ & $13 \cdot 0-24 \cdot 5$ & \\
\hline
\end{tabular}

Table 3 Relationship of median $\% S+G_{2}$ of 97 adenomas $(>5 \mathrm{~mm})$ from 20 cases of FAP related to type of adenoma and degree of dysplasia

\begin{tabular}{|c|c|c|c|c|c|c|}
\hline & \multicolumn{3}{|l|}{ Type } & \multicolumn{3}{|c|}{ Degree of dysplasia } \\
\hline & Tubular & Tubulovillous & Villous & Mild & Moderate & Severe \\
\hline Adenomas/(n) & 46 & 48 & 3 & 43 & 39 & 15 \\
\hline Median $\% \mathrm{~S}+\mathrm{G}_{2}$ & $18 \cdot 4$ & $18 \cdot 3$ & $24 \cdot 3$ & $18 \cdot 4$ & $18 \cdot 7$ & $20 \cdot 8$ \\
\hline Range & $5 \cdot 5-33.9$ & $9 \cdot 6-31 \cdot 5$ & $19 \cdot 9-27 \cdot 7$ & $5 \cdot 5-28 \cdot 1$ & $7.6-33.9$ & $12 \cdot 6-31 \cdot 5$ \\
\hline 25th-75th centile & $14 \cdot 4-22 \cdot 6$ & $15 \cdot 0-21 \cdot 9$ & - & $14 \cdot 6-20 \cdot 9$ & $14 \cdot 2-22 \cdot 5$ & $17 \cdot 4-27 \cdot 7$ \\
\hline
\end{tabular}

Table 4 Relationship of median $\% S+G_{2}$ of 100 randomly selected sporadic colorectal adenomas to size, type, and degree of dysplasia of adenoma

\begin{tabular}{|c|c|c|c|c|c|c|c|c|c|}
\hline & \multicolumn{3}{|l|}{ Size } & \multicolumn{3}{|l|}{ Type } & \multicolumn{3}{|l|}{ Dysplasia } \\
\hline & $<1 \mathrm{~cm}$ & $1-2 \mathrm{~cm}$ & $>2 \mathrm{~cm}$ & Tubular & Tubulovillous & Villous & Mild $^{*}$ & Moderate* & Severe \\
\hline Adenomas (n) & 53 & 35 & 12 & 70 & 24 & 6 & 16 & 55 & 29 \\
\hline Median $\% S+G_{2}$ & $15 \cdot 6$ & $17 \cdot 7$ & $16 \cdot 8$ & $16 \cdot 2$ & $19 \cdot 4$ & $16 \cdot 4$ & $12 \cdot 8$ & $17 \cdot 8$ & $16 \cdot 4$ \\
\hline Range & $6 \cdot 9-32 \cdot 2$ & $8 \cdot 3-32 \cdot 9$ & $9 \cdot 8-24 \cdot 4$ & $6.9-32.9$ & $9 \cdot 8-32 \cdot 9$ & $11 \cdot 3-25 \cdot 0$ & $6 \cdot 9-26 \cdot 9$ & $8 \cdot 3-32 \cdot 9$ & $8 \cdot 5-32 \cdot 9$ \\
\hline 25th-75th centile & $12 \cdot 6-20 \cdot 5$ & $13 \cdot 2-20 \cdot 9$ & $15 \cdot 4-21 \cdot 6$ & $13 \cdot 1-20 \cdot 2$ & $15 \cdot 4-27 \cdot 5$ & $11 \cdot 4-23 \cdot 6$ & $11 \cdot 6-16 \cdot 2$ & $13 \cdot 7-21 \cdot 1$ & $15 \cdot 2-23 \cdot 1$ \\
\hline
\end{tabular}

${ }^{*}$ Significantly lower $\% S+G_{2}$ in mildly dysplastic adenomas $v$ moderate $(p<0.005)$ or severe dysplasia $(p<0.01)$.

cases in the absence of carcinoma suggests that DNA content is of no value as a specific clinical indicator of the likely development of malignant disease, a finding recently suggested for ulcerative colitis. ${ }^{14}$ The high incidence of DNA aneuploidy in FAP patients is caused by the number of adenomas per case as the overall incidence in all FAP adenomas is only $12 \%$. All combinations of DNA content in adenomas and carcinomas were seen in the patients with carcinomas and no definite relationship was demonstrable with age at presentation or the size of the largest adenoma present in the colorectum. Some trends were observed with the more frequent finding of carcinoma in the older age group, however, and those with larger synchronous adenomas. Related stemlines were seen in two cases, one of which is reported in greater detail elsewhere ${ }^{10}$ where related stemlines were observed over an 11 year period suggesting that, as in ulcerative colitis,,$^{14}$ the development of DNA aneuploid stemlines may not be a random event.
DNA aneuploidy developed at a much earlier stage in FAP than in sporadic adenomas ${ }^{23}$ being present in $15 \%$ of 'microadenomas' $(<1 \mathrm{~mm}), 18 \%$ of early adenomas $(<5 \mathrm{~mm})$, and $11.2 \%$ of those from 5-9 $\mathrm{mm}$. The true incidence in the first two categories can only be regarded as a rough estimate because of the necessity of measuring multiple small lesions in tissue sections. As with sporadic adenomas, DNA content was found to increase with increasing degrees of dysplasia and to be more frequent in villous and tubulovillous types, though these findings did not reach significance as they have in previous studies with sporadic adenomas. ${ }^{1-3} 15$

CELL PROLIFERATION

The median $\% S+G_{2}$ value and the range were similar in sporadic and FAP adenomas. In the former, a difference emerged between mildly dysplastic adenomas and those with more severe degrees of dysplasia although this was not seen in the FAP adenomas. In the FAP cases large adenomas ( $>5$ 
$\mathrm{mm}$ ) had a higher median level of proliferation $(18.6 \% v 15.4 \%)$ than smaller adenomas $(<5 \mathrm{~mm})$ with no difference between the degrees of dysplasia. The median level of cell proliferation in sporadic $(16.4 \%)$ and FAP $(15.8 \%)$ adenomas is significantly higher than that found in 88 samples of normal mucosa $(14.2 \% \text { : } p<0.005 \text { Mann-Whitney } U \text { test })^{10}$ and significantly lower than that reported in 88 diploid adenocarcinomas (24\%: $p<0.001$ MannWhitney U test ${ }^{16}$ measured under the same conditions. Thus the level of cell proliferation appears to increase throughout the adenoma-carcinoma sequence.

Familial adenomatous polyposis appears to differ from sporadic adenomas in the early development of DNA aneuploidy, but not in the level of cell proliferation. The underlying genetic cause of this difference is unknown although the occurrence of the genetic abnormality of in vitro tetraploidy has been demonstrated to occur in FAP. ${ }^{1720}$ Whether in vivo tetrapolidy is a frequent early event possibly leading to DNA aneuploidy is a matter for further investigation, though no flow cytometric evidence of the former was seen in this study.

We would like to thank Mrs C L North, Mr N Dudding, and Mr R Stretton for excellent technical assistance and Mrs Jacquie Fearnley for typing the manuscript. We are grateful to the Yorkshire Cancer Research Campaign for financial support.

Presented at the 154th Meeting of the Pathological Society of Great Britain and Ireland, 1987.

\section{References}

1 Weiss $\mathrm{H}$, Wildner GP, Jacobasch $\mathrm{K}-\mathrm{H}$, Heinz U, Schaelicke W. Characterisation of human adenomatous polyps of the colorectal bowel by means of DNA distribution patterns. Oncology 1985; 42: 33-41.

2 Quirke P, Fozard JBJ, Dixon MF, Dyson JED, Giles GR, Bird CC. DNA aneuploidy in colorectal adenomatous polyps. Br J Cancer 1986; 53: 477-81.

3 Goh HS, Jass JR. DNA content and the adenomacarcinoma sequence in the colorectum. J Clin Pathol 1986; 39: 387-92.

4 Brown LJR, Smeeton NC, Dixon MF. Assessment of dysplasia in colorectal adenomas: an observer variation and morphometric study. J Clin Pathol 1985; 38: 174-9.

5 Bussey HJR. Familial polyposis coli. Baltimore: John Hopkins University Press, 1975.
6 Ekelund G, Lindstrom C. Histopathological analysis of benign polyps in patients with carcinoma of the colon and rectum. Gut 1974; 15: 654-63.

7 Kozuka S. Premalignancy of the mucosal polyp in the large intestine: 1 Histological gradation of the polyp on the basis of epithelial pseudostratification and glandular branching. Dis Colon Rectum 1975; 18: 483-93.

8 Konishi F, Morson BC. Pathology of colorectal adenomas: a colonoscopic survey. J Clin Pathol 1982; 35: 830-41.

9 Hedley DW, Friedlander ML, Taylor IW, Rugg CA, Musgrove EA. Method for analysis of cellular DNA content of paraffin-embedded pathological material using flow cytometry. J Histochem Cytochem 1983; 31: 1333-5.

10 Quirke P. The role of flow cytometry in the assessment of the pathobiology of colorectal neoplasia. University of Leeds: PhD Thesis, 1987.

11 Hiddemann W, Schumann J, Andreeff M, et al. Convention on nomenclature for DNA Cytometry. Cytometry 1984; 5: 445-6.

12 Maeda M, Iwama T, Ustunomiya J, Aoki N, Suzuki S. Radiological features of familial polyposis coli: grouping by polyp profusion. $\mathrm{BrJ}$ Radiol 1984; 57: 217-22.

13 Muto T, Bussey HJR, Morson BC. The evolution of cancer of the colon and rectum. Cancer 1975; 36: 2251-70.

14 Fozard JBJ, Quirke P, Dixon MF, Giles GR, Bird CC. DNA aneuploidy in ulcerative colitis. Gut 1986; 17: 1414-8.

15 Van den Ingh HF, Griffioen G, Cornelisse CJ. Flow cytometric detection of aneuploidy in colorectal adenomas. Cancer Res 1985; 45: 3392-7.

16 Quirke P, Durdey P, Dixon MF, Dyson JED, Williams NS, Bird CC. The prognostic significance of DNA aneuploidy and cell proliferation in rectal adenocarcinomas. J Pathol 1987; 151: 285-92.

17 Danes BS. Increased tetraploidy: Cell specific for the Gardner gene in the cultured cell. Cancer 1976; 38: 1983-8.

18 Danes BS, Alun T, Neale OMA. Modifying alleles in the heritable colorectal cancer syndromes with polyps. In: Winawer S, ed. Colorectal cancer prevention. Epidemiology and screening. New York: Raven Press, 1980: 73.

19 Danes BS, Deschner EE. Detection of in vitro tetraploidy in heritable colon cancer syndromes. Cancer 1984; 54: 1353-9.

20 Rider SH, Mazzullo HA, Davis MB, Delhanty JDA. Familial polyposis coli: growth characteristics of karyotypically variable cultured fibroblasts response to epidermal growth factor and the tumour promoter 12-0tetradecanoyl phorbol-13-acetate. J Med Genet 1986; 23: 131-44. 